\title{
EFFECT OF COMPACTIVE EFFORT ON STRENGTH INDICES OF LATERITE TREATED WITH CALCIUM CARBIDE WASTE
}

\author{
M. JOEL AND L. J. JOSEPH
}

(Received 14 July 2015; Revision Accepted 16 October 2015)

\begin{abstract}
The effect of British Standard Light (BSL), West African Standard (WAS) and British standard Heavy (BSH) compactive efforts on the strength indices oflaterite treated with 2, 4, 6 and $8 \%$ calcium carbide waste (CCW) was studied. Atterberg's limits test, compaction test, California bearing ratio (CBR) and unconfined compressive strength (UCS) tests were performed on laterite treated with CCW. Unconfined compressive strength and California bearing ratio values of Ikpayongo laterite used as strength indices increased with higher compactive effort and $\mathrm{CCW}$ content. CBR value of the natural laterite increased from $10 \%, 17 \%$ and $18 \%$ to peak values of $23.0 \% 47 \%$ and $50 \%$ respectively, when treated with $\%$ CCW, using BSL, WAS and BSH compactive effort respectively. 7 day UCS values of the natural laterite using BSL, WAS and BSH compactive efforts increased from 397, 620 and $640 \mathrm{kN} / \mathrm{m}^{2}$ to peak values of 1450,1456 and $1457 \mathrm{kN} / \mathrm{m}^{2}$, respectively, when treated with $8 \% \mathrm{CCW}$. Results of tests showed that compactive effort have effect on strength indices of laterite treated with CCW. The WAS compactive effort was recommended for use as the most economic compactive effort in the treatment of laterite with CCW for use in road work. Outcome of the study will provide a useful guide in the use of CCW for road work.
\end{abstract}

KEYWORDS: compactive effort, strength indices, calcium carbide waste.

\section{INTRODUCTION}

Laterite, a sedimentary rock deposit arising from the weathering of rocks, is one of the most common and readily available road building materials that can be sourced locally in Nigerian. Laterite has been defined by different authors using different criteria, but for simplicity and ease of understanding, Ola (1983) defined laterite as the products of tropical weathering with red, reddish brown, and dark brown colour, with or without nodules or concreting and generally (but not exclusively) found below hardened ferruginous crust or hard pan.

At Ikpayongo, a distance of 22 kilometres from Makurdi, the capital of Benue State of Nigeria, West-Africa, large deposit of laterite is found, the deposit is divided into two equal parts by the main road linking Makurdi to Otukpo. Ikpayongo laterite deposit is located in the Benue trough (which is more than 800 kilometres in length and varies in width from 100 kilometres in the south to about 150 kilometres in the north. The Benue trough is conventionally divided into three sections; the lower, Middle and the Upper. According to (Rahaman and Malomo, 1983) sedimentation in all the sections started in the cretaceous (Albian) and ended at Upper-most Cretaceous times (Maestrichtian). The lower section where Ikpayongo laterite deposit is situated is dominated by the Abakaliki anticlinorium. Maximum thickness in the lower section estimated by (Cratchley and Jones, 1965) from gravity study probably does not exceed 4300 meters. (Ford, 1989) describe laterite found in the Benue trough as a residual weathering product on partially or wholly decomposed basalts and other basic to intermediate igneous rocks.

Laterite obtained from Ikpayongo has

M. Joel, Civil Engineering Department, University of Agriculture, PMB 2373, Makurdi, Benue State, Nigeria.

L. J. Joseph, Civil Engineering Department, University of Agriculture, PMB 2373, Makurdi, Benue State, Nigeria. 
been the main source of borrow material for road construction in Makurdi town. It has been used as base and sub-base course material of most of the flexible pavement built within the metropolis. Different types of defects have been observed in almost all the areas where the natural laterite was used as sub-base or base material, this observation is a pointer to the fact that the suitability of the material needs to be assessed. Makasa, (2007) and Thagesen (1996) observed that defect associated with use of laterite in road work can be attributed to poorly graded particlesize, highclay content, and the degree to which the soils have been compacted. The deficiencies associated with laterite according to researchers can be overcome through stabilization. Lime and cement have been meaningfully used for soil stabilization and modification as reported by (Reids and Brooks, 1999; Basha, et al, 2005; Eze-Uzomaka and Agbo, 2010; Joel and Agbede, 2011; Joel and Agbede, 2010).

Laterite from Ikpayongo was reported by Joel and Agbede, 2011; Eze-Uzomaka and Agbo, 2010) as not suitable for use as sub-base and base material and cannot be treated economically for use as pavement material with only cement.Since it has been observed that only cement cannot effectively stabilize Ikpayongo laterite, there is need for a modifier or admixture in the stabilization of Ikpayongo laterite with cement. However lime which seems to be the conventional material used in soil modification is very expensive, the cost of lime is three times the equivalent cost by volume of cement, hence the need for an alternative.

Recent trend in research works in the field of geotechnical engineering and highway construction materials focuses more on cheaper and locally available materials as alternative to conventional stabilization agent, used to upgrade the strength indices of soils. One of such readily available material that can be used to replace lime in the stabilization of laterite with high plasticity index is calcium carbide waste.CCW is a by-product recovered from the production of acetylene gas $\left(\mathrm{C}_{2} \mathrm{H}_{2}\right)$ used in oxy-acetylene welding. It consists mainly of $\left(\mathrm{Ca}(\mathrm{OH})_{2}\right)$ lime, caustic solid substances, and white in appearance when pure. Calcium carbide waste is normally dumped at different locations, especially mechanic villages and industries where oxyacetylene gas welding is carried out. Such sites and locations are common features in most urban centres and some rural areas, in Nigeria. Calcium carbide waste is normally disposed via land fill or open dumping which have effect on surface and ground water, arising from the leaching of harmful compounds and alkali to ground and surface water. Therefore, alternative means of disposal are desirable. Utilization of the waste material to upgrade the engineering properties of laterite would serve as one of the disposal outlets.

Treatment of soil with stabilization agent to help improve soil strength may be referred to as soil modification or stabilization, depending on treatment objective. Soil modification as described by Sariossieri and Muhunthan, (2009) applies to a significant improvement of the soil workability and compaction characteristics and to a minor improvement of the soil mechanical strength using low contents of stabilizers. Modification according to (Eluozo and Nwaobakata, 2013) refers to soil improvement that occurs in the short term, during or shortly after mixing (within hours). It is aimed at reducing plasticity of the soil to the desired level, short term strength gain, (i.e. strength derived immediately after application to about 7-days of compaction).

Stabilization as defined by Peurifoy et al. (2006) is any treatment given to soil with the aim of achieving increases in strength. Such treatment are categorized into Mechanical and chemical stabilization. Moses and Osinubi (2013) refers to soil stabilization as any process which improves the engineering properties of deficient soils and subsequently enables them to perform and sustain their intended engineering use. Soil stabilization is aimed at improving soil strength, decrease permeability and water absorption, improve soil bearing capacity and durability under adverse weather condition. Compaction plays a critical role in the achievement of these goals as a loosely packed soil cannot attain the desired objective without densification. In most civil engineering work where stabilization is adopted, compaction normally preceded the addition and mixing of a "stabilization agent.

Compaction according to Punmia, Jain and Jain (2005) is a process by which the soil particles are artificially rearranged and packed together into a closer state of contact by mechanical means in order to decrease the porosity (or voids ratio) of the soil and thus increase its density. Aysen (2005) refers to compaction as the process of reducing the air content by the application of energy to the moist soil.During compaction Sharma (2008) reported 
that soil particles are constrained to pack more closely together through a reduction in air voids, generally by mechanical means.

Punmia, Jain and Jain (2005) observed that compaction is aimed at improvement of some soil properties such as, reduction of compressibility, water absorption and permeability, increase in soil strength, bearing capacity. The aim of compaction according to Peurifoy, et al (2006) is to reduce or prevent settlements, increase strength, improve bearing capacity, control volume change, and lower permeability of soil.Good earthworks compaction according to O'Flaherty (2002) increases soil bearing capacity, ensure slope stability, reduces settlements, and undesirable volume changes, ensures the uniform behavior of the pavement and prevents differential settlements.

The dry density of soil produced by compaction according to Punmia, Jain, and Jain (2005) and Sharma (2008) is influenced by moisture content, the amount as well as method of application of the compactive effort, type of soil, and addition of admixtures. Garber and Hoel (2010) reported a link between strength and soil dry density as the researchers postulated that the strength of the compacted soil is directly related to the maximum dry density achieved through compaction, an indication that compaction is very vital to soil stabilization.

Compaction in the field may be accomplished through the use of different compaction equipmentsuch as sheep foot rollers, tamping rollers, smooth-drum vibratory soil compactors, pad-drum vibratory soil compactors, pneumatic-tired rollers. These rollers apply energy by one or more of the following methods, to cause compaction, impact (sharp blow) pressure (static weight) vibration (Shaking) and Kneading (Manipulation or re arranging).In the field the number of passes of the rollers is normally correlated with the desired compactive effort through the use of in situ density tests. The test is normally performed using any of the following methods; the sand-replacement method, the core cutter method, the rubber balloon method, soil penetrometers and several new methods.

Soil compaction in the field begins with compaction test in the laboratory, used to determine water-density relationships of soils. Such relationship normally serves as a guide in the implementation of compaction on the field. Compaction in the laboratory is performed with the aid of cylindrical moulds and standard rammers. Energy is applied to soil sample placed in the mould through a rammer of standard size and mass dropping freely from a standard height onto layers of soil sample in the mould. Soil specimens are placed in the mould in 3 or 5 layers with a specified number of blows applied to each layer. The energy given to a unit volume of soil is referred to as compactive effort. Garber and Hoel (2010) referred to compactive effort as a measure of the mechanical energy imposed on the soil mass during compaction. The energy per unit volume, $E$ is determined using equation (1).

$$
E=\frac{(\text { NOB }) X \text { (NOL) } x \text { (WOH) } x(D H O R)}{\text { Volume of mould }}
$$

NOB; Number of Blows, NOL; Number of Layers, WHO; Weight of Hammer,

DHOR; Drop Height of Rammer.

The commonly used energies in Nigeria is $\begin{array}{lll}\text { Tabulated in } & \text { Table }\end{array}$

Table 1: Variables of the Different compactive Efforts used in Nigeira.

\begin{tabular}{|l|l|l|l|l|l|}
\hline $\begin{array}{l}\text { Compactive } \\
\text { Effort }\end{array}$ & $\begin{array}{l}\text { Weight of } \\
\text { Rammer } \\
(\mathrm{kg})\end{array}$ & $\begin{array}{l}\text { Number of } \\
\text { Blows per } \\
\text { layer }\end{array}$ & $\begin{array}{l}\text { Number } \\
\text { of layers }\end{array}$ & $\begin{array}{l}\text { Drop Height } \\
\text { of Rammer } \\
(\mathrm{m})\end{array}$ & $\begin{array}{l}\text { Compaction } \\
\text { Energy } \\
\left(\mathrm{kN}-\mathrm{m} / \mathrm{m}^{3}\right)\end{array}$ \\
\hline BSL & 2.5 & 27 & 3 & 0.30 & 595.95 \\
\hline WAS & 4.5 & 10 & 5 & 0.45 & 993.26 \\
\hline BSH & 4.5 & 27 & 5 & 0.45 & 2681.80 \\
\hline
\end{tabular}

Source: (Osinubi and Nwaiwu, 2006)

BSL = British Standard Light Compaction,

WAS $=$ West African standard Compaction,

$\mathrm{BSH}=$ British Standard Heavy Compaction. 
The compaction characteristics of laterite treated with different stabilizing agents have been researched into and reported by different researchers. However, not much has been done on the compaction characteristics of laterite treated with CCW. Thus, the aim of this study is to evaluate the strength gain of Ikpayongo laterite treated with CCW when compacted at different energy levels. Gain in strength will be assessed using the unconfined compressive strength and CBR results as strength indices.

\section{MATERIALS AND METHODS}

Laterite sample was collected from Ikpayongo, located at a distance of 22 kilometres from Makurdi, the capital of Benue State, Nigeria, along Makurdi- Otukpo road. The borrow pit was located at a distance of $800 \mathrm{~m}$ and at an angle of $90^{\circ}$ East from the centre line of the road. Disturbed samples were collected at a depth of 0.5 to $2.0 \mathrm{~m}$ after the removal of the top soil. CCW was collected from a welder located at the North bank mechanic village area of Makurdi. It was dried in the open air, and grinded into fine particles, using pestle and mortar (in the absence of a ball mill and made to pass through the 300 $\mu \mathrm{m}$ B.S sieve). Chemical analysis of CCW was carried out using $\mathrm{x}$-ray analyzer together with Atomic Absorption Spectrophotometer (AAS).

Laboratory tests were performed on the sample obtained from lkpayongo in accordance with BS1377 (1990) for the natural laterite and BS1924 (1990) for laterite mixed with CCW. California bearing ratio (CBR) tests were conducted in accordance with the Nigerian General Specification for road and Bridges (1997) which stipulated that specimens be cured in the dry for six days then soaked for 24 hours before testing. Tests performed on lkpayongo laterite sample mixed with $\mathrm{CCW}$ include, Atterberg's limits tests, compaction tests, Unconfined Compressive strength (UCS) tests and California bearing ratio tests.

Compaction tests were carried out using energies derived from the standard proctor (SP),
West African Standard (WAS) and British Standard heavy (BSH) energies. The SP compactions was carried out using energy derived from a rammer of $2.5 \mathrm{Kg}$ mass falling through a height of $0.30 \mathrm{~m}$ in a $1.0 \times 10^{-3} \mathrm{~m}^{3}$ mould. The soil was compacted in three layers, each receiving 27 blows. The CBR compaction involved the use of the same rammer weight and drop height with each layer receiving 62 blows in a $2.360 \times 10^{-3} \mathrm{~m}^{3}$ mould. The WAS compaction, was carried out using energy derived from a rammer of $4.5 \mathrm{~kg}$ mass falling through a height of $0.45 \mathrm{~m}$ in a $1.0 \times 10^{-3} \mathrm{~m}^{3}$ mould. The soil was compacted in five layers, each layer receiving 10 blows. CBR compaction was carried out using the same rammer weight and drop height was adopted with each layer receiving 30 blows in a $2.360 \times 10^{-3} \mathrm{~m}^{3}$ mould. The BSH compaction was carried out using energy derived from a rammer $4.5 \mathrm{~kg}$ mass falling through a height of $0.45 \mathrm{~m}$ in a $1.0 \times 10^{-3} \mathrm{~m}^{3}$ mould. The soil was compacted in 5 layers, each receiving 27 blows. The CBR compaction involved the same rammer weight and drop height with each layer receiving 62 blows in a $2.360 \times 10^{-3} \mathrm{~m}^{3}$ mould.

UCS test specimens were compacted at the SP, WAS and BSH energy levels. Specimens were cellophane cured for 7,14 and 28 days before testing. The resistance to loss in strength was determined as a ratio of the unconfinedcompressivestrength (UCS) of specimens cured for 7 days under controlled conditions, which were subsequently immersed in water for another 7 days to the UCS of specimens cured for 14 days. The particle size distribution of the laterite was determined using the wet sieving method.

\section{RESULTS AND DISCUSSION}

The particle size distribution curve of Ikpayongo laterite, is presented in Figure 1, while some geotechnical properties of the laterite is presented in Table 1.The chemical analysis of CCW is summarized in Table 2 . 


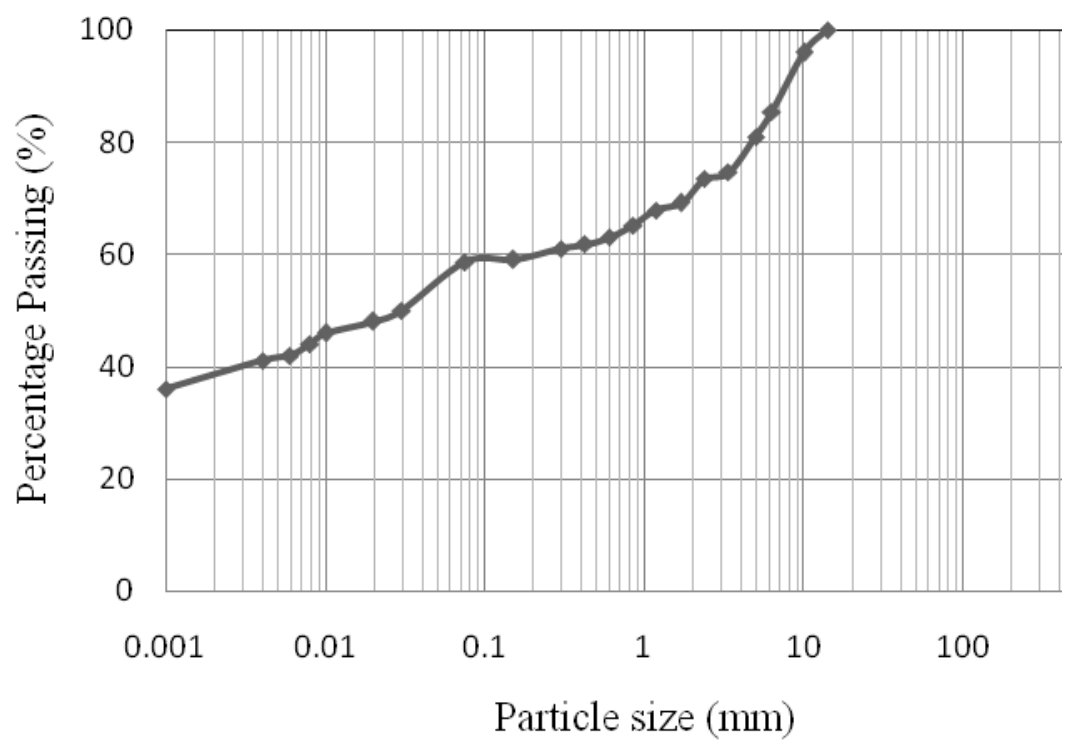

Fig. 1: particle size distribution curve of Ikpayongo Iaterite.

Table 1: Some Geotechnical Properties of Ikpayongo Laterite.

\begin{tabular}{|c|c|}
\hline Property & Quantity \\
\hline Percentage Passing BS Sieve No 200 (\%) & 37 \\
\hline Liquid Limit, (\%) & 39 \\
\hline Plastic Limit (\%) & 20 \\
\hline Plasticity Index (\%) & 14 \\
\hline AASHTO Classification & A-2-6 \\
\hline USCS Classification & GC \\
\hline Maximum Dry Density, (BSL)Mg/m ${ }^{3}$ & 1.71 \\
\hline Optimum Moisture Content (BSL) (\%) & 15 \\
\hline Maximum Dry Density, (WAS)Mg/m ${ }^{3}$ & 1.85 \\
\hline Optimum Moisture Content (WAS) (\%) & 12 \\
\hline Maximum Dry Density, $(\mathrm{BSH}) \mathrm{Mg} / \mathrm{m}^{3}$ & 1.95 \\
\hline Optimum Moisture Content (BSH) (\%) & 9 \\
\hline Unconfined Compressive Strength (BSL)kN/m² & 396 \\
\hline Unconfined Compressive Strength (WAS) $\mathrm{kN} / \mathrm{m}^{2}$ & 620 \\
\hline Unconfined Compressive Strength (BSH)kN/m² & 640 \\
\hline California Bearing Ratio, (BSL)\% (after 24hrs soaking) & 10 \\
\hline California Bearing Ratio, (WAS)\% (after 24hrs soaking) & 17 \\
\hline California Bearing Ratio, (BSH)\% (after 24hrs soaking) & 17 \\
\hline Specific Gravity & 2.69 \\
\hline Colour & Reddish brown \\
\hline Natural Moisture Content (\%) & 6.90 \\
\hline
\end{tabular}


Table 2: Chemical Composition of Calcium Carbide Waste.

\begin{tabular}{|l|l|l|l|l|l|l|l|}
\hline Elemental Oxide & $\mathrm{CaO}$ & $\mathrm{MgO}$ & $\mathrm{Al}_{2} \mathrm{O}_{3}$ & $\mathrm{Fe}_{2} \mathrm{O}_{3}$ & $\mathrm{SiO}_{2}$ & $\mathrm{SO}_{3}$ & $\mathrm{LOI}$ \\
\hline $\begin{array}{l}\text { Percentage } \\
\text { Composition (\%) }\end{array}$ & 61.41 & 0.80 & 1.78 & 0.17 & 2.69 & 0.36 & 32.51 \\
\hline \multicolumn{8}{|c|}{ LOI: Loss on Ignition. }
\end{tabular}

Ikpayongo laterite was found to be an A2-6 and GC soil using the AASHTO and Unified Soil Classification Systems (USCS) respectively. The specific gravities of Ikpayongo laterite, and CCW were determined to be 2.69 , and 1.90 , respectively. The geotechnical properties of Ikpayongo laterite reflected in Table 1 shows that it is not suitable for use as sub-base and base material using the Nigerian General Specification for road and bridges (1997) requirements, hence the need for stabilization to make it suitable for use as sub-base and base material.

The Atterberg's limits test result of Ikpayongo laterite treated with $\mathrm{CCW}$ is reflected in Table 3. The addition of CCW to Ikpayongo laterite improves its consistency indices, as the plasticity index reduced from $42 \%$ to $15 \%$ when treated with $8 \% \mathrm{CCW}$. Variation of liquid limit, plastic limit and plasticity index of Ikpayongo laterite with $\mathrm{CCW}$ can be attributed to cation exchange, aggregation and pozzolanic reaction between the clay mineral in the laterite and CCW. The liquid limit of Ikpayongo laterite decreased from $52 \%$ to $42 \%$ when treated with $8 \%$ CCW. The plastic limit increased from $10 \%$ to $27 \%$ when treated with $8 \% \mathrm{CCW}$, thereby resulting in the reduction in the plasticity index of Ikpayongo laterite.

Table 3: Atterberg's Limits of Ikpayongo Laterite Treated with Calcium Carbide Waste.

\begin{tabular}{|l|l|l|l|l|l|}
\hline $\begin{array}{l}\text { Calcium carbide waste } \\
\text { content (\%) }\end{array}$ & 0 & 2 & 4 & 6 & 8 \\
\hline Liquid Limit & 39 & 37 & 35 & 34 & 33 \\
\hline Plastic Limit & 20 & 22 & 23 & 24 & 25 \\
\hline Plasticity Index & 19 & 15 & 12 & 10 & 15 \\
\hline Linear Shrinkage & 16 & 16 & 13 & 11 & 9 \\
\hline
\end{tabular}

LL= Liquid Limit (\%), PL = Plastic Limit, (\%), PI = Plasticity Index, (\%).

The variation of maximum dry density and optimum moisture content of Ikpayongo laterite treated with $\mathrm{CCW}$ at the different compactive effort is presented in Figures 2 and 3 respectively. 


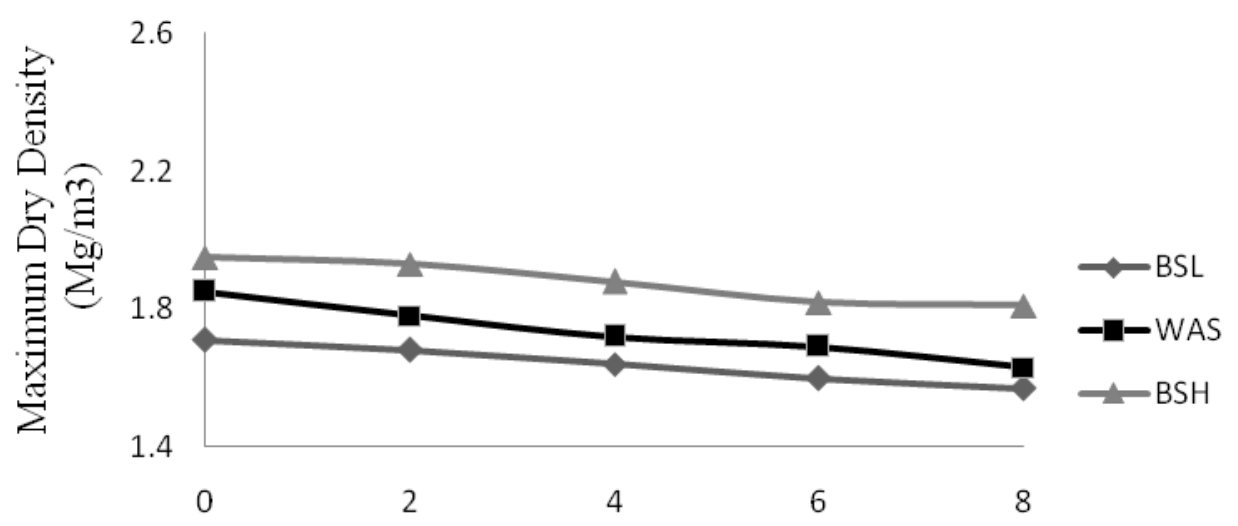

Calcium carbide waste content $(\%)$

Fig. 2: Variation of Maximum Dry Density with Calcium carbide waste and Compactive effort.

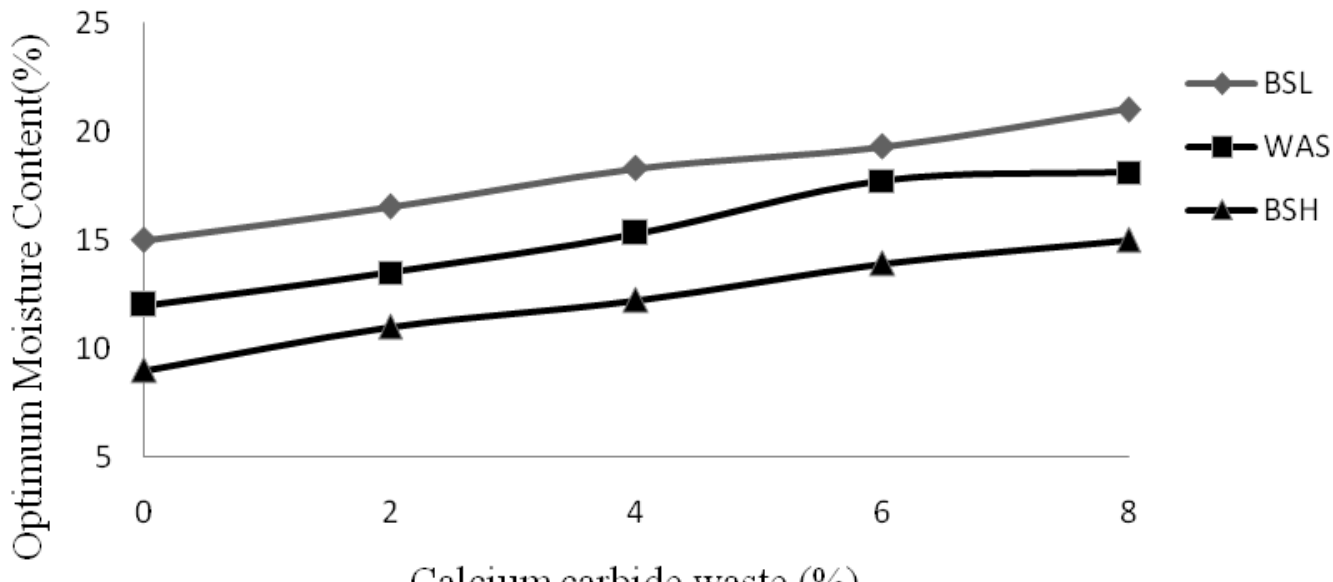

Calcium carbide waste $(\%)$

Fig.3: Variation of Optimum moisture content with Calcium carbide waste content and compactive effort.

The maximum dry density of Ikpayongo laterite decrease with $\mathrm{CCW}$ content and increased with higher compactive effort. The decrease in the MDD of Ikpayongo laterite with CCW content can be attributed to a decrease in the surface area of the clay fraction of Ikpayongo laterite and the cation exchange, aggregation and pozzolanic reaction of CCW with the clay fraction of the laterite. The maximum dry density of the untreated laterite decreased from 1.71,1.85 and $1.95 \mathrm{Mg} / \mathrm{m}^{3}$ to $1.57,1.63$, and $1.81 \mathrm{Mg} / \mathrm{m}^{3}$ when treated with $8 \% \mathrm{CCW}$, at the BSL, WAS and $\mathrm{BSH}$ energy levels respectively. Optimum moisture content (OMC) of Ikpayongo laterite increased from 15, 12, and $9 \%$ to $21,18.1$ and $15 \%$ when treated with $8 \% \mathrm{CCW}$, using BSL, WAS, and $\mathrm{BSH}$ energy levels respectively. The increase in optimum moisture content can be 
attributed to more moisture required for effective reactions of CCW.

UCS result used as one of the strength indices and durability tests results of Ikpayongo laterite treated with $\mathrm{CCW}$ at the different energy level is presented in Table 4.

Table 4: Variation of Unconfined Compressive Strength with compactive effort and CCW.

\begin{tabular}{|l|l|l|l|l|l|}
\hline Calcium carbide waste & $0 \%$ & $2 \%$ & $4 \%$ & $6 \%$ & $8 \%$ \\
\hline 7 day UCS $(\mathrm{BSL})$ & 397 & 433 & 546 & 1382 & 1450 \\
\hline 14 day UCS $(\mathrm{BSL})$ & 400 & 553 & 860 & 1425 & 1515 \\
\hline 28 day UCS $(\mathrm{BSL})$ & 400 & 1093 & 1280 & 1462 & 1580 \\
\hline 7 day UCS $(\mathrm{WAS})$ & 620 & 620 & 778 & 1413 & 1456 \\
\hline 14 day UCS $(\mathrm{WAS})$ & 620 & 1031 & 1259 & 1453 & 1537 \\
\hline 28 day UCS $(\mathrm{WAS})$ & 620 & 1113 & 1270 & 1537 & 1549 \\
\hline 7 day UCS $(\mathrm{BSH})$ & 640 & 670 & 1144 & 1456 & 1457 \\
\hline 14 day UCS $(\mathrm{BSH})$ & 647 & 1061 & 1363 & 1469 & 1642 \\
\hline 28 day UCS $(\mathrm{BSH})$ & 650 & 1334 & 1436 & 1577 & 1673 \\
\hline
\end{tabular}

7 dUCS = Seven day Unconfined Compressive Strength, $\mathrm{kN} / \mathrm{m}^{2}$

14 dUCS = Fourteen day Unconfined Compressive strength, $\mathrm{kN} / \mathrm{m}^{2}$

28 dUCS = Twenty eight day Unconfined Compressive strength, $\mathrm{kN} / \mathrm{m}^{2}$

Seven (7) day UCS value of Ikpayongo laterite increased from $397 \mathrm{kN} / \mathrm{m}^{2}$ to $1450 \mathrm{kN} / \mathrm{m}^{2}$, $620 \mathrm{kN} / \mathrm{m}^{2}$ to $1456 \mathrm{kN} / \mathrm{m}^{2}$, and $640 \mathrm{kN} / \mathrm{m}^{2}$ to $1457 \mathrm{kN} / \mathrm{m}^{2}$ when Ikpayongo laterite was treated with $8 \% \mathrm{CCW}$ using BSL, WAS and BSH energy levels respectively. Increase in strength with CCW can be attributed to cation exchange, pozzolanic and carbonation reaction of CCW. The trend observed with 7 day UCS values was observed with 14 and 28 day UCS values.

The resistance to loss of strength of Ikpayongo laterite treated with $\mathrm{CCW}$ is presented in Figure 4. The resistance to loss of strength value of Ikpayongo laterite increased from $0 \%$ to maximum values of 53,64 and 70 when treated with $8 \% \mathrm{CCW}$, using BSL, WAS and $\mathrm{BSH}$ energy levels respectively. The minimum resistance to loss of strength value of $20 \%$ specified by Ola (1974) was not satisfied at $8 \%$ CCW using the three energy levels. However, resistance to loss of strength of Ikpayongo laterite improved with increased energy level. 


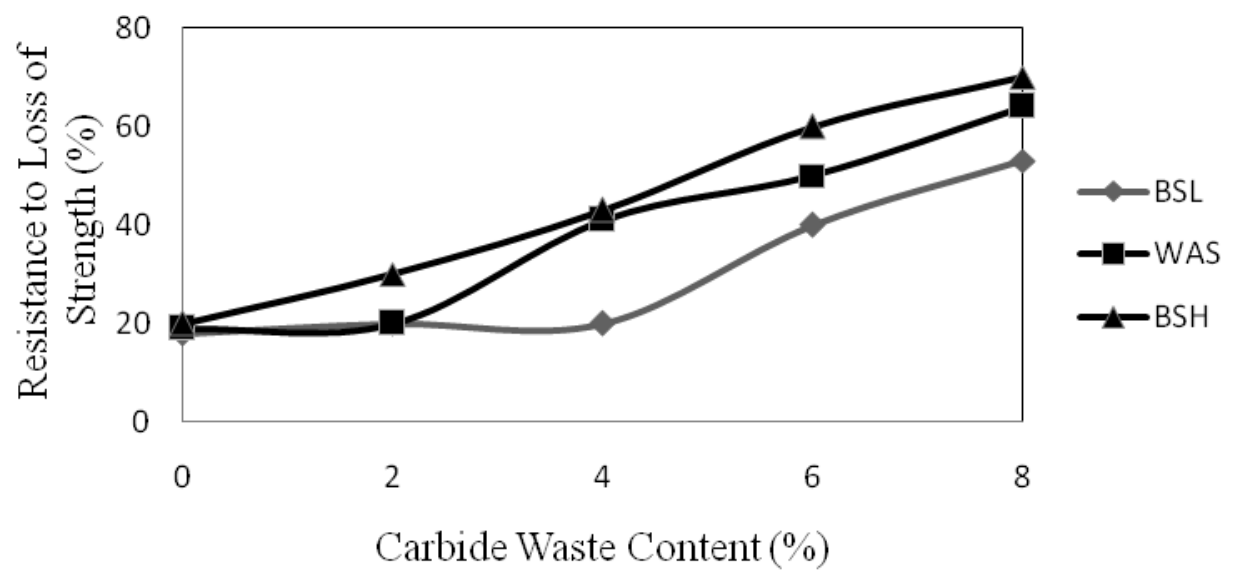

Fig. 4: Variation of Resistance to Loss of Strength with

Carbide waste content $(\%)$

California bearing ratio value of Ikpayonog laterite treated with $\mathrm{CCW}$, at the three energy levels studied is presented in Figure 5.

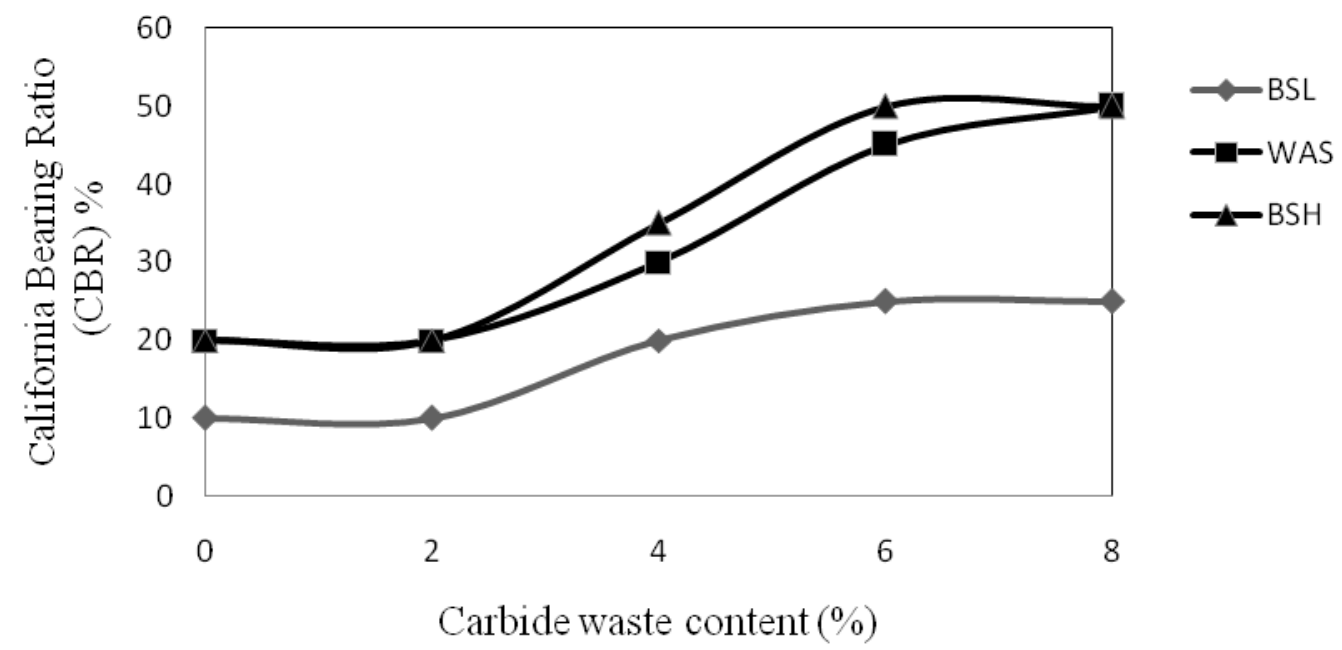

Fig. 5: Variation of California Bearing Ratio with Carbide waste content $(\%)$

California bearing ratio (CBR) value of Ikpayongo laterite increased from $10 \%$ to $25 \%$, $20 \%$ to $50 \%$ and $20 \%$ to $55 \%$ when treated with $8 \% \mathrm{CCW}$ using BSL, WAS, and BSH energy levels respectively. The use of CCW and different energy levels enhanced the CBR values of Ikpayongo laterite. Using the minimum 7day UCS value of $1034.25 \mathrm{kN} / \mathrm{m},{ }^{2}$ CBR values of 40 $\%, 80 \%$ and $100 \%$ at BSL for subbase, base of lightly traffic road and base (heavily trafficked 
roads) specified by Osinubi (1999), Ikpayongo laterite treated with $\mathrm{CCW}$ is only suitable for use as subbase material in the construction of flexible pavement. CBR and UCS values shows that strength indices of Ikpayongo laterite improved with higher energy level. Hence the recommendation of the use of $\mathrm{CCW}$ in the stabilization of Ikpayongo laterite for use in road work. Where higher strength values are desired, the use of CCW as a modifier, in the stabilization of laterite is recommended.

\section{CONCLUSIONS}

from the study,

1. The liquid limit of Ikpayongo laterite decreased with CCW content while the plastic limit increased with CCW content resulting in decrease in plasticity index, as the plasticity index of Ikpayongo laterite decreased from $14 \%$ to $5 \%$, when treated with $8 \% \mathrm{CCW}$.

2. Maximum dry density of Ikpayongo laterite decreased with $\mathrm{CCW}$ content while it increased with higher compactive effort. The Optimum Moisture Content (OMC) of Ikpayongo laterite increased with CCW content, while it decreased with higher energy level.

3. Strength indices of Ikpayongo laterite measured using CBR and UCS test result shows that $C B R, 7,14$ and 28 day UCS values increased with CCW content and higher compactive effort.

4. Based on the analysis of different tests performed on sample of laterite obtatined from Ikpayongo, laterite treated with $8 \%$ CCW is recommended for use as subbase material in pavement work, using the WAS energy level.

\section{REFERENCES}

Aysen, A., 2005. Soil mechanics: Basic concepts and engineering application. Taylor and Francis, New York.

British Standards (BS)., 1377. 1990. Methods of Testing Soils for Civil Engineering Purposes. British Standards Institution: London, Uk.
British standards (BS)., 1924. 1990. Methods of Test for Stabilized Soils. British Standards Institution: London, Uk.

Basha, E. A., Hashim, R., Mahmud, H. B and Muntohar, A. S., 2005. Stabilization of residual soil with rice husk ash and cement. Construction and Building Materials. 19, 448-453.

Cratchley, C. R and Jones, G. P., 1965. An interpretation of the geology and gravity anomalies of the Benue valley, Nigeria. Overseas Geol. Surv. London. Geophys. Paper 1.

Eluozo, S. N and Nwaobakata, C., 2013. Predictive models to determine the behaviour of plastic and liquid limit of lateritic soil for road construction at Egbema: Imo state of Nigeria. International Journal of Engineering and Technology. 2, (1): 25-31.

Eze-Uzomaka, O. J and Agbo, D., 2010. Suitability of quarry dust as improvement to cement Stabilized-laterite for road bases. Electronic Journal of Geotechnical Engineering. 15, (k): 10531066.

Ford, O. S., 1989. The economic mineral resources of the Benue trough. In C.A. Kogbe, (Editor), Geology of Nigeria. Rock View, Jos, Nigeria. Pp.473-484.

Garber, J. N and Hoel, L. A., 2010. Traffic and highway engineering. Cengage Learning, Philadelphia, USA.

Joel, M and Agbede. I. O., 2011. Mechanicalcement stabilization of laterite for use a flexible pavement material. Journal of Materials in Civil Engineering. 23, (2):146-152.

Joel, M and Agbede, I. O., 2010. Cement stabilization of Igumale shale lime admixtures for use as flexible pavement construction material. Electronic Journal of Geotechnical Engineering. 15, 16611673. 
Nigerian General Specification., 1997. Roads and Bridges Works. Federal Ministry of Works and Housing, Lagos, Nigeria.

Makasa, B., 2007. Utilization and improvement of laterite gravels in road bases. International Institute for Aerospace Survey and earth science (ITC), Delft, Netherlands.

Moses, $G$ and Osinubi, K.J., 2013. Influence of compactive efforts on Cement-Bagasse Ash treatment of expansive black cotton soil. World Academy of Scinece, Engineering and Technology. 7 (28) : 1841-1848.

O'Flaherty, C. A., 2002. Highways: The location, design, construction and maintenance of Pavements ( $4^{\text {th }}$ edition). Elsevier, India.

Ola, S. A., 1983. Geotechnical properties and behaviour of some Nigerian lateritic soils. In S. A. Ola, (Editor.), Tropical soils of Nigeria in engineering practice. A.A. Balkema/Rotter dam, Netherlands, PP.61-84.

Ola, S. A., 1974. Need for estimated cement requirements for stabilization of Laterite Soils. Journal of Transportation Engineering Division, ASCE, 100, (2):379-388.

Osinubi, K. J and Nwaiwu, M. O. C., 2006. Design of compacted lateritic soil liners and covers. Journal of Geotechnical and Geoenvironmental Engineering. 132, (12): 203-213.

Osinubi, K. J., 1999. Evaluation of admixture stabilization of Nigeria black cotton soil. Nigerian Society of Engineers, Technical Transactions. 34, (3): 88-96.
Peurifoy, L. R., Schexnayder, J. C and Shapira, A., 2006. Construction planning, equipment and methods $\left(7^{\text {th }}\right.$ edition). Mc. Graw Hill, New York.

Punmia, C. B., Jain, K. A and Jain, K. A., 2005. Soil Mechanics and Foundations (16 ${ }^{\text {th }}$ edition). Laxmi publications, New delhi.

Rahaman, A. M and Malomo, S., 1983. Sedimentary and Crystalline rocks of Nigeria. In S. A. Ola, (Editor), Tropical soils of Nigeria in engineering practice. A.A. Balkema/Rotter dam, Netherlands, pp17-38.

Reid, J. M and Brooks, H. A., 1999. Investigation of Lime stabilized contaminated soils. Engineering Geology. 53, 217-231.

Sariossieri, F and Muhunthan, B., 2009. Effect of cement treatment on geotechnical properties of some Washington state soils. Engineering Geology. 104, (2): 119-125.

Sharma, K. S., 2012 . Principles, practice and design of highway engineering (Revised edition). S.Chand and Company Ltd, New Delhi.

Thagesen, B., 1996. Tropical rocks and soils. In B. Thageson, (Editor), Highway and Traffic engineering in developing countries. Chapman and Hall, London. 